\title{
INTRODUCTION TO SYMPOSIUM ON FRAMING GLOBAL MIGRATION LAW - PART II
}

\author{
Jaya Ramji-Nogales* and Peter J. Spiro ${ }^{\dagger}$
}

Part I of this symposium on framing global migration law introduced broad conceptual parameters of a new field, looking back to its international law roots and forward to a new orientation beyond the strictures of refugee law. ${ }^{1}$ Part II looks to situate global migration law along a range of theoretical dimensions. Jacqueline Bhabha establishes the continuities of human movement in a historical context, modern and premodern. ${ }^{2}$ Far from representing a radical departure, the current migration "crisis" is consistent with massive migrations over the ages. Tendayi Achiume considers migration through the lens of colonization and decolonization. ${ }^{3}$ Out-migration from Europe was a core economic element of the colonization project; Achiume suggests that contemporary migration from former dependencies to metropolitan powers will correct co-dependencies that continue to advantage postcolonial powers. Focusing Achiume's lens on the problem of human trafficking, Janie Chuang complicates the binary depictions of economic migration that underpin contemporary international law. ${ }^{4}$ She suggests that global migration law's grounding in a migrant-centered perspective could help state actors to understand the structural causes of modern-day exploitation, enabling a shift from a crime control approach to a human mobility paradigm.

Ibrahim Awad examines the uneven distribution of migration norms, rules, activities, and institutions at four levels: international, regional, national, and subnational. ${ }^{5}$ He notes the primacy of national level decision-making in the migration realm and posits that this sovereignty-based approach undermines the effectiveness of global governance of migration. Diego Acosta explores free movement regimes and their effectiveness at the regional level, with South America's MERCOSUR Residence Agreement as a case study. ${ }^{6}$ Intergovernmental dialogue, supranational non-legally-binding committees, and national courts present three possible enforcement vehicles beyond supranational courts for such regional accords.

Loren Landau highlights the precarity of formal legal rights for refugees and other migrants on the ground in urban centers of the South, calling for an elevation of the social, political, and spatial in efforts to advance migrant protections. ${ }^{7}$ Landau also sets forth a strategy of stealth humanitarianism by deepening solidarities with nonmigrant populations, which are often more vulnerable than migrant counterparts. Finally, Martin Ruhs advocates a

* I. Herman Stern Professor of Law at Temple University Beasley School of Law, Co-Director of the Institute for International Law and Public Policy.

+ Charles R. Weiner Professor of Law at Temple University Beasley School of Law, Co-Director of the Institute for International Law and Public Policy.

${ }^{1}$ See Jaya Ramji-Nogales \& Peter J. Spiro, Introduction to Symposium on Framing Global Migration Law, 111 AJIL UnBound 1 (2017).

2 Jacqueline Bhabha, Human Mobility and the Longue Durée: The Prebistory of Global Migration Law, 111 AJIL UnBound 136 (2017).

${ }^{3}$ E. Tendayi Achiume, Reimagining International Law for Global Migration: Migration as Decolonization?, 111 AJIL UNBOUND 142 (2017).

${ }^{4}$ Janie A. Chuang, Using Global Migration Law to Prevent Human Trafficking, 111 AJIL UnBound 147 (2017).

${ }^{5}$ Ibrahim Awad, The Multiple Levels of Governance of International Migration: Understanding Disparities and Disorder, 111 AJIL UNBOUND 153 (2017).

${ }^{6}$ Diego Acosta, Global Migration Law and Regional Free Movement: Compliance and Adjudication - The Case of South America, 111 AJIL UNBOUND 159 (2017).

${ }^{7}$ Loren B. Landau, Southern Urbanism, Legalization, and the Limits of Migration Law, 111 AJIL UnBound 165 (2017).

\footnotetext{
The American Society of International Law, Jaya Ramji-Nogales and Peter J. Spiro ( 2017. This is an Open Access article, distributed under the terms of the Creative Commons Attribution licence (http://creativecommons.org/licenses/by/4.0/), which permits unrestricted re-use, distribution, and reproduction in any medium, provided the original work is properly cited.
} 
"core rights" approach with respect to migrants. ${ }^{8}$ Efforts to pursue comprehensive protections beyond civil and political rights through treaty instruments have failed to win a significant number of accessions, and empirical evidence suggests that the extension of broader rights for migrants is correlated with constricted admissions. The rights-openness trade-off suggests that a core rights approach will aggregately benefit prospective migrants by facilitating greater levels of regularized migration. This group of essays (the second of three in this symposium on global migration law) demonstrates the broad range of vectors - temporal, disciplinary, and scalar among them - engaged in conceptualizing global migration law.

${ }^{8}$ Martin Ruhs, Rethinking International Legal Standards for the Protection of Migrant Workers: The Case for a "Core Rights" Approach, 111 AJIL UnBOUND 172 (2017). 